\title{
Quantitative Trait Loci and Candidate Genes Affecting Fatty Acid Composition in Cattle and Pig
}

\author{
Dyah Maharani, Cheorun Jo, Jin-Tae Jeon ${ }^{1}$, and Jun Heon Lee* \\ Department of Animal Science and Biotechnology, Chungnam National University, Daejeon 305-764, Korea \\ ${ }^{1}$ Division of Applied Life Science, Gyeongsang National University, Jinju 660-701, Korea
}

\begin{abstract}
Investigations into fatty acid composition in meats are becoming more important due to consumer demand for high quality healthy food. Marker-assisted selection has been applied to livestock to improve meat quality by directly selecting animals for favorable alleles that affect economic traits. Quantitative trait loci affecting fatty acid composition in cattle and pigs were investigated, and five candidate genes (ACACA, FASN, SCD, FABPs, and SREBP-1) were significantly associated with fatty acid composition. The information presented here should provide valuable guidelines to detect causative mutations affecting fatty acid composition in cattle and pigs.
\end{abstract}

Key words: quantitative trait locus, candidate genes, fatty acid composition, cattle, pig

\section{Introduction}

Dietary fatty acids (FAs) found in meat, dairy products, vegetables, nuts and fish are highly relevant nutrients for human health that influence the risk for several human health problems including heart disease, stroke, diabetes and some cancers (FAO, 2003). High intake of saturated FA (SFA) can result in elevated plasma cholesterol, which leads to cardiovascular disease. SFAs such as lauric acid (C12:0), myristic acid (C14:0) and palmitic acid (C16:0) most deleteriously influence cardiovascular health (Keys et al., 1974). In contrast, monounsaturated FAs (MUFAs) and polyunsaturated FAs (PUFAs) decrease the circulating concentration of low density lipoprotein (LDL)-cholesterol by increasing hepatic LDL receptor activity (Woolet et al., 1992).

The FA composition of meat is one of the main factors defining meat quality parameters including nutrition, sensory and functional aspects. Meat quality can be improved by an increasing the ratio of UFA to SFA (Yang et al., 1999). The variation in FA composition, in particular saturation, affects the firmness and oiliness of adipose tissue (Diana et al., 1998; Wood et al., 2008) that also influ-

\footnotetext{
*Corresponding author: Jun-Heon Lee, Department of Animal Science and Biotechnology, Chungnam National University, Daejeon 305-764, Korea. Tel: 82-42-821-5779, Fax: 82-42825-9754, E-mail: junheon@cnu.ac.kr
}

ences meat processing. Moreover, FAs are important in controlling cellular metabolism, maintaining an intact cell membrane and improving nutrient use (Kim et al., 2006). Oxidative stability of muscle can be affected by FA composition, which in turn affects muscle flavor and muscle color, increasing consumer acceptance. Some studies have been reported the important effects of fatty acid to meat quality. The lower melting point of monounsaturated fatty acid (MUFA) contributes positively to beef flavor and tenderness (Melton et al., 1982; Smith et al., 2006). For example, one of the major MUFAs in beef fat, oleic acid (C18:1) is not susceptible to oxidation and contribute to favorable tenderness and flavor of beef (Westerling and Hendrick 1979; Melton et al., 1982). In contrast, high melting point fat in meat appears whiter than the fats having lower melting point. This indicates fat color was affected by fatty acids (Wood et al., 2003). In case of beef texture, the increase of $\mathrm{C} 18: 1$ in relation to $\mathrm{C} 18: 0$ and C16:0 effects soft and oily fat. Therefore, producing and selecting animals having desirable high quality meat with healthy FA composition has become an important goal of producers and researchers.

With the aim of producing healthier meat, dietary alterations have been successful in altering the FA composition with respect to the content of UFA in pigs, poultry and fish (Bou et al., 2009; Jung et al., 2010; Kim et al., 2007). However, the FA composition of meat from ruminants is generally more saturated and is difficult to alter 
because UFAs are subject to biohydrogenation in the rumen (Decker and Park, 2010). This is one of the reasons for the temporally steady or slowly decreasing consumption in beef or other animal products from ruminants in many countries.

The selection of animals having important traits including FA composition can be achieved using molecular approaches such as quantitative trait loci (QTL, locations of the genes on the chromosomes affecting quantitative traits) and candidate genes. For this selection, identification of the QTL regions harboring the candidate genes is crucial, and preludes the search for influential gene mutations in these regions. A number of studies have investigated the chromosomal regions and/or genetic variations affecting FA composition by using QTL analyses and candidate gene identification. This article provides a summary overview of the study of QTLs and candidate genes in relation to FA composition in economically important animals including cattle and pigs.

\section{QTL for FA Composition}

The locations of the genes on the chromosomes affecting quantitative traits are referred as quantitative trait loci (QTLs). Therefore, the identification of QTL regions is very important because the causative mutation for FA composition can be searched from these regions. Ultimately, the identified causative mutations can be used for the selection of animals having desirable (healthy) FA composition.

Meat quality is multifactorial trait that influenced by genetic and non-genetic factors. Usually, the genetic factors can be improved by conventional breeding methods. However, if the causative mutations were identified for the economic traits (in this case meat quality), then marker assisted selection can be applied for selection of better animals in early stage. Initially, the polymorphic markers were identified across the genome of interest and the associations were tested between markers and traits. If the significant location of chromosome was identified, this region of the genome is called QTL region (Beuzen, et al., 2000).

\section{QTLs affecting FA composition in cattle}

Many of the known bovine QTLs are summarized on the National Animal Genome Research Program website (http://www.animalgenome.org/QTLdb). As of December 2010, this database contained 4,281 QTLs collected from 235 study reports. The QTLs represent 359 traits. In par- ticular, the traits include six classes: exterior, health, meat, milk, production and reproduction. Among these, meat-related traits represent only $7.4 \%$ of the QTLs thus far identified. None of the top 20 traits based on the number of reported QTLs are related to FA composition, reflecting the paucity of FA-related QTL studies that have been carried out in cattle.

A whole-genome scan using $328 \mathrm{~F}_{2}$ progenies from a Wagyu and Limousine cross was conducted by Alexander et al. (2007). They identified QTLs affecting palatability and FA composition in beef. Seven QTLs affecting lipid metabolisms and tenderness were identified in five chromosomes. Another, more recent study was conducted using the population from crosses between Charolais and Holstein based on the balanced $\mathrm{F}_{2}$ and backcross breeding designs. A whole-genome scan was carried out to detect QTLs affecting FA composition in beef (Gutierrez-Gil et al., 2010). The QTL locations are summarized in Table 1.

The latter study indicates that many loci are responsible for the variation of FA composition (Guitierrez et al., 2010). The highest number of QTLs was detected on chromosome 10 near the $133 \mathrm{cM}$ region: in particular, QTLs for the content of gamma-linolenic acid (C20:3n-6) and docosapentaenoic acid (C22:5n-3, DPA) were present and displayed a $5 \%$ genome-wide significance level. The second half of this chromosome, at position $91 \mathrm{cM}$, was also shown to harbor a significant QTL for docosahexaenoic acid (C22:6n-3, DHA).

In chromosome 1, at around $51 \mathrm{cM}$, three QTLs for linoleic acid (C18:2n-6), linolenic acid (C18:3n-3) and polyunsaturated fatty acids (PUFAs) were detected (Table 1). These three traits displayed different chromosomewide significance levels. Linoleic acid and PUFA had 1\% chromosome-wide significance levels, whereas linolenic acid showed a $5 \%$ chromosome-wide significance level. Only linoleic acid had genome-wide significance $(0.042$, Table 1). Chromosome-wide significance levels of $1 \%$ were also detected on chromosome 8 (C20:4n-6), 9 (C20:5n-3), 10 (C20:3n-6 and C22:5n-3) and 22 [C16:0; C16:1; 9cC18:1; conjugated linoleic acid (CLA)] and the weight of total FAs. In addition, fat thickness, another fatrelated trait, was detected in chromosome 1 and 7 in the cross population between Brahman and Hereford (Casas et al., 2003) and Japanese Black (Wagyu) cattle (Mizoguchi et al., 2006). In Wagyu cattle, a significant QTL was detected for arachidonic acid (C20:4n-6) on BTA13 and, in the same location, but a QTL for subcutaneous fat depth was not identified (Mizoguchi et al., 2006). In a QTL study in Wagyu and Limousine cattle, QTLs for 
Table 1. QTL locations affecting fatty acid composition in cattle

\begin{tabular}{|c|c|c|c|c|}
\hline Trait $^{1}$ & $\begin{array}{l}\text { Cattle chromo- } \\
\text { some }\end{array}$ & Position (cM) & $\mathrm{Pc}^{2}(\mathrm{Pg})^{3}$ value & Reference \\
\hline C18:2n-6; C18:3n-3; PUFA & 1 & $51 ; 51 ; 51$ & $0.0025(0.042) ; 0.0446 ; 0.0053$ & Gutierrez et al. (2010) \\
\hline n6:n3 & 2 & 91 & 0.031 & Gutierrez et al. (2010) \\
\hline CLA; MUFA; SFA & 2 & $46 ; 5 ; 10$ & $(0.013) ;(0.00012) ;(0.01)$ & Alexander et al. (2007) \\
\hline $\mathrm{R}_{2}$ (ratio of $\mathrm{C} 16: 1$ to $\mathrm{C} 16: 0$ ) & 2 & 4 & $(0.00032)$ & \\
\hline $\mathrm{R}_{3}$ (ratio of $\mathrm{C} 18: 1$ to $\mathrm{C} 18: 0$ ) & 2 & 0 & $(0.00002)$ & \\
\hline SFA; MUFA; PUFA & 2 & $4 ; 4 ; 11$ & $(0.04) ;(<0.01) ;(<0.01)$ & Tshipuliso et al. (2008) \\
\hline CLA & 4 & 92 & 0.0196 & Gutierrez et al. (2010) \\
\hline 11t C18:1 (trans vaccenic) & 5 & 93 & 0.037 & Gutierrez et al. (2010) \\
\hline C18:0_ald; C22:6n-3; ln-n-6:n-3 & 6 & $29 ; 12 ; 24$ & $0.0374 ; 0.0405 ; 0.046$ & Gutierrez et al. (2010) \\
\hline CLA; MUFA; SFA; & 7 & $131 ; 125 ; 125$ & $(0.092) ;(0.025) ;(0.065)$ & Alexander et al. (2007) \\
\hline C18:2n-6; C20:4n-6; & 8 & $0 ; 0$ & $0.0359 ; 0.0058$ & Gutierrez et al. (2010) \\
\hline C22:5n-3; PUFA & & $0 ; 0$ & $0.0451 ; 0.0153$ & \\
\hline $\mathrm{C} 20: 5 n-3 ; \mathrm{C} 22: 6 \mathrm{n}-3$ & 9 & $0 ; 75$ & $0.0098 ; 0.0248$ & Gutierrez et al. (2010) \\
\hline MUFA; PUFA & 9 & $119 ; 54$ & $(0.09) ;(<0.01)$ & Tshipuliso et al (2008) \\
\hline C:16_ald; $11 \mathrm{cC} 18: 1 ;$ & 10 & $133 ; 0$ & $0.0203 ; 0.0157$ & Gutierrez et al. (2010) \\
\hline$C 20: 3 n-6 ; C 22: 5 n-3$ & & 133(4-133); 133 (1-133); & $0.0013(0.024) ; 0.0008(0.015)$ & \\
\hline C22:6n-3; n-3PUFA & & $91 ; 133$ & $0.043 ; 0.054$ & \\
\hline PUFA & 10 & 38 & $(0.02)$ & Tshipuliso et al. (2008) \\
\hline $\mathrm{C} 20: 5 n-3$ & 11 & 89 & 0.0184 & Gutierrez et al. (2010) \\
\hline MUFA; SFA & 12 & $0 ; 0$ & $(0.128) ;(0.052)$ & Alexander et al. (2007) \\
\hline$C 20: 4 n-6$ & 13 & 5 & 0.0155 & Gutierrez et al. (2010) \\
\hline PUFA & 15 & 14 & $(<0.01)$ & Tshipuliso et al. (2008) \\
\hline n6:n3 & 18 & 55 & 0.0114 & Gutierrez et al. (2010) \\
\hline $11 \mathrm{cC} 18: 1$ & 20 & 9 & 0.0043 & Gutierrez et al. (2010) \\
\hline C14:0; C16:0; C16:1; & 22 & $29 ; 31 ; 33 ; 29$ & $0.0142 ; 0.0053 ; 0.0041$ & Gutierrez et al. (2010) \\
\hline C18:0; 9cC18:1; CLA; & & $35 ; 29 ; 32$ & $0.0239 ; 0.0032 ; 0.008$ & \\
\hline SUMWFA; SFA; P:S & & $30 ; 32$ & $0.0092 ; 0.0112 ; 0.012$ & \\
\hline
\end{tabular}

${ }^{1}$ Trait: C14:0 = myristic acid; C16:0 = palmitic acid; C16:0_ald = palmitic aldehyde; C16:1 = palmitoleic acid; C18:0 = stearic acid; $\mathrm{C} 18: 0$-ald = stearic aldehyde acid; $11 \mathrm{tC} 18: 1=$ trans vaccenic acid; $9 \mathrm{cC} 18: 1=$ oleic acid; $11 \mathrm{cC} 18: 1=$ cis vaccenic acid; $\mathrm{C} 18: 2 \mathrm{n}-6=$ linoleic acid; C18:3n-3 = linolenic acid; CLA = conjugated linoleic acid; C20:3n-6 = gamma-linolenic acid; C20:4n-6 = arachidonic acid; C20:5n-3 = timnodonic acid; C22:5n-3 = docosapentaenoic acid (DPA); C22:6n-3 = docosahexaenoic acid (DHA); SUMWFA = weight of total fatty acids $(\mathrm{mg} / 100 \mathrm{~g})$; SFA = saturated fatty acids; PUFA = poly-unsaturated fatty acids; n-3 PUFA = n-3 poly-unsaturated fatty acids; $P: S=$ poly-unsaturated:saturated fatty acid ratio; $n-6: n-3=n-6: n-3$ ratio. MUFA=mono-unsaturated fatty acid

${ }^{2} \mathrm{Pc}$-value $=$ chromosome-wide $p$-value

${ }^{3} \mathrm{Pg}$-value $=$ genome-wide $p$-value (the percentage in side of $($ ), it means the level significant in genome-wide)

SFAs, MUFAs and PUFAs were reported on BTA 2 (Tshipuliso et al., 2008). QTLs on BTA 10 and 22 were indicative of an association with PUFA (at position 38 $\mathrm{cM}$ ) and MUFA (at position $47 \mathrm{cM}$ ), respectively.

QTLs located on chromosome 2 showing less than 5\% and $1 \%$ genome-wide significance effects included CLA at $46 \mathrm{cM}(p=0.013)$, MUFA at $5 \mathrm{cM}(p=0.00012)$, SFA at $10 \mathrm{cM}(p=0.01), \mathrm{R}_{2}$ at $4 \mathrm{cM}(p=0.00032)$ and $\mathrm{R}_{3}$ at $0 \mathrm{cM}$ $(p=0.00002)$ (Table 1). These reported QTLs were consistent with those in Wagyu and Limousin populations, which showed increasing lipid content, stearyl-CoA desaturase and desirable flavor. However, Alexander et al. (2007) reported that the fat-related genes such as FA synthase (FASN), acetyl-CoA carboxylase alpha (ACACA), solute carrier family 2 member 4 (SLCA4), stearyl-CoA desaturase (SCD) and the gene encoding the subunit of FA elongase were not located in 7 reported QTL regions. GutierrezGil et al. (2010) also provided similar evidence that these genes were not good positional candidate genes for the QTLs detected in chromosome 4. Only the leptin gene 
(LEP) corresponded with the QTL detected in the flanking interval between DIK26 and IDVG51 on chromosome 4. However, a previous study implicated FASN on chromosome 19 (19q22) as being responsible for FA compositions (Roy et al., 2001). Especially, the thioesterase domain of FASN located in exons 39-42 (Bhuiyan et al., 2009, Zhang et al., 2008) and exon 34 (Abe et al., 2009) significantly affected the FA composition. Also, gene ACACA on BTA 19 was implicated in the de novo synthesis of FAs (Zhang et al., 2009). In addition, the SCD gene located on bovine chromosome 26 has been significantly linked with MUFA, stearic and oleic acids in Japanese Black cattle (Ohsaki et al., 2009).

Interestingly, a QTL location can be associated with multiple traits. For example, a QTL on chromosome 11 was highly correlated with C20:5n-3 (Gutierrez-Gil et al. 2010) and other traits such as yield force and abnormal odor intensity (Gutierrez-Gil et al., 2008). Gutierrez-Gil et al. (2010) also reported that no QTL was detected for MUFA. However, another study detected QTLs for MUFA on BTA 2, 7 and 12 (Alexander et al., 2007) and BTA 9 and BTA 22 (Tshipuliso et al., 2008). MUFA also was detected on chromosome 19 (Taylor et al., 1998). Three QTLs on BTA 1, 8 and 10 (Gutierrez et al., 2010) and BTA 2, 9 and 15 (Tshipuliso et al., 2008) were identified for PUFAs. These results indicate the complexity of the QTLs; especially, some of the related traits have the same QTL locations. This also indicates that many factors influence FA composition. FA modification and synthesis in ruminant animals can be affected by feeding systems (Alfaia et al., 2009; Noci et al., 2007) and breed (MalauAduli et al., 1998; Zhang et al., 2007)

\section{QTLs affecting fatty acid composition in pigs}

The National Animal Genome Research Program database (http://www.animalgenome.org/QTLdb) lists 1705 porcine QTLs. In total, 5986 pig QTLs representing 581 different pig traits have been reported in 268 publications. The number of QTLs in relation to meat quality traits ranked as the most prevalent (69.2\%) in comparison with other classes including exterior $(6.3 \%)$, health $(9.8 \%)$, production (10.1\%) and reproduction (4.6\%). Several fat characteristics such as average backfat thickness, backfat at rib, intramuscular fat (IMF) content and subcutaneous fat depth are among the top 20 most numerous of identified the QTLs. Similarly with the cattle QTL database, traits concerning FA composition are not among the 20 most prevalent traits. However, the number of pig QTL studies in relation to FA composition was more than that of cattle.

The significant QTLs affecting palmitoleic acid (C16: 1) has been detected in SSC1 (Sus scrofa Chromosome 1) and SSC9 (Nii et al., 2006). Another studies also detected QTLs for palmitoleic at SSC12 (Munoz et al., 2007) and SSC8 (Clop et al., 2003). Sanchez et al. (2007) also reported two QTLs on SSC10 and SSC12, which had significant associations (5\% chromosome-wide level) and one QTL on SSC14 with a 1\% genome-wide significance with palmitoleic acid. Palmitoleic acid located in different QTL locations on SSC13 and SSC12 has been reported (Guo et al., 2009; Uemoto et al., 2009). While QTLs for palmitoleic acid are located in various chromosomal regions, the QTLs for stearic acid (C18:0) and linoleic acid (C18:2) are located in more than 50\% chromosomal regions (Table 2). The different populations and breeds used in above three studies may explain the variability of QTL locations for palmitoleic acid.

Only one QTL location was detected both for palmitic acid (C16:0; SSC3) and linoleic acid (C18:2; SSC17). Eighteen QTL locations for 11 FA composition traits were detected in SSC4, whereas 13 QTL locations were detected in SSC7 for 17 FA composition traits. However, two QTL locations in SSC7 at position $62 \mathrm{cM}$ and $59 \mathrm{cM}$ had only a suggestive link and were not significantly associated with C16:1 (Uemoto et al., 2009). In the X chromosome, five QTLs regions have been identified in relation to FA composition (Guo et al., 2009).

An analysis of 153 QTLs including 63 genome-wide significant QTLs and 90 suggestive QTLs revealed significant effects for FA composition traits on SSC4, 7, 8, 10,13 and $\mathrm{X}$, with no effects evident on SSC3 and 11 (Guo et al., 2009). Interestingly, the QTL observed on SSC 7 for C20:1 displayed an unusually high $F$-value of 118.71 (Table 2). In addition, FA compositions detected in longissimus muscle and abdominal fat showed similar QTL locations. However, the different characteristics of two muscle types were reflected in the distinct QTL effect on SSC8 for FA composition in abdominal fat and longissimus dorsi. Significant pleiotropic effects in chromosome 4 and 7 were evident for MUFA and PUFA in both longissimus muscle and abdominal fat. The same study reported that QTL affecting FA in both tissues (longissimus muscle and abdominal fat) were always located at different positions on the same chromosome. This indicates that the genetic factor may influence the FA composition in different tissues.

Clop et al. (2003) detected FA composition QTLs using F2 crosses between Iberian and Landrace pigs. The QTLs 
Table 2. QTL locations affecting fatty acid composition in pig

\begin{tabular}{|c|c|c|c|c|}
\hline Trait $^{1}$ & $\begin{array}{l}\text { pig } \\
\text { chromosome }\end{array}$ & Position (cM) & $\mathrm{Pc}^{2}(\mathrm{Pg})^{3}$ value & Reference \\
\hline $\mathrm{C} 16: 1 ; \mathrm{C} 18: 0$ (inner layer backfat) & 1 & $20.1 ; 16.1$ & Significant & Nii et al. (2006) \\
\hline C16:1; C18:0 (outer layer backfat) & 1 & $22.8 ; 23.8$ & Significant & Nii et al. (2006) \\
\hline $\mathrm{C} 18: 2$ & 1 & 60.7 & Significant & Lee et al. (2003) \\
\hline C18:1; C18:2n-6; MUFA; P:S & 1 & $124 ; 29 ; 122 ; 29$ & $5 \% ; 1 \% ; 5 \% ; 5 \%$ & Sanchez et al. (2007) \\
\hline C18:1(perirenal fat) & 2 & 63.2 & Significant & Nii et al. (2006) \\
\hline$C 22: 5 n-6$ & 2 & 122 & $5 \%$ & Sanchez et al. (2007) \\
\hline $\mathrm{C} 16: 0$ (perirenal fat) & 3 & 87.8 & Significant & Nii et al. (2006) \\
\hline $\mathrm{C} 18: 2$ & 4 & 68 & $(\mathrm{P}<0.05)$ & Kim et al. (2006) \\
\hline $\mathrm{C} 18: 2$ & 4 & $79 ; 59$ & $(1 \%) ;(1 \%)$ & Guo et al. (2009) \\
\hline $\mathrm{C} 18: 3$ & 4 & $81 ; 59$ & $(1 \%) ;(1 \%)$ & Guo et al. (2009) \\
\hline C18:1 & 4 & 53 & $(1 \%)$ & Guo et al. (2009) \\
\hline $\mathrm{C} 20: 2 ; \mathrm{C} 20: 2 ; \mathrm{C} 20: 3 ; \mathrm{C} 20: 4$ & 4 & $76 ; 60 ; 61 ; 64$ & $(5 \%) ;(1 \%) ;(1 \%) ;(1 \%)$ & Guo et al. (2009) \\
\hline MUFA & 4 & $79 ; 55$ & $(1 \%) ;(1 \%)$ & Guo et al. (2009) \\
\hline PUFA & 4 & $79 ; 58$ & $(1 \%) ;(1 \%)$ & Guo et al. (2009) \\
\hline C18:2 ; DBI; PI & 4 & $75 ; 73 ; 75$ & $(p<0.01 ; p=0.02 ; p<0.01)$ & Clop et al. (2003) \\
\hline C18:2 (inner layer back fat & 4 & 69.7 & Significant & Nii et al. (2006) \\
\hline C18:2 (perirenal fat) & 4 & 65.5 & Significant & Nii et al. (2006) \\
\hline C18:1 & 4 & 71.6 & Significant & Nii et al. (2006) \\
\hline $\mathrm{C} 18: 2$ and $\mathrm{C} 18: 1$ & 4 & 81 & $(p<0.01)$ & Perez-Enrico et al. (2000) \\
\hline$C 22: 5 n-6$ & 4 & 117 & $5 \%$ & Sanchez et al. (2007) \\
\hline $\mathrm{C} 18: 2$ & 5 & 49 & Significant & Uemoto et al. (2009) \\
\hline PUFA (inner layer back fat) & 5 & 48.0 & Significant & Nii et al. (2006) \\
\hline PUFA (perirenal fat) & 5 & 49.9 & Significant & Nii et al. (2006) \\
\hline MUFA & 5 & 118 & $5 \%$ & Sanchez et al. (2007) \\
\hline $\mathrm{C} 16: 0$ (perirenal fat) & 6 & 73.2 & Significant & Nii et al. (2006) \\
\hline DBI;UI & 6 & $105 ; 34$ & $(p=0.04 ; p=0.05)$ & Clop et al. (2003) \\
\hline $\mathrm{C} 18: 1$ & 7 & 26 & $(p<0.05)$ & Kim et al. (2006) \\
\hline C18:3 & 7 & $50 ; 57$ & $(1 \%) ;(1 \%)$ & Guo et al. (2009) \\
\hline C18:1 & 7 & $57 ; 55$ & $(1 \%) ;(1 \%)$ & Guo et al. (2009) \\
\hline MUFA & 7 & $57 ; 55$ & $(1 \%) ;(1 \%)$ & Guo et al. (2009) \\
\hline $\mathrm{C} 18: 2$ & 7 & $58 ; 59$ & $(1 \%)$ & Guo et al. (2009) \\
\hline $\mathrm{C} 20: 3 ; \mathrm{C} 20: 1 ; \mathrm{C} 20: 4$ & 7 & $59 ; 71 ; 71$ & $(1 \%) ;(1 \%) ;(1 \%)$ & Guo et al. (2009) \\
\hline C16:0; SFA; P/S & 7 & $92 ; 92 ; 55$ & $(1 \%) ;(5 \%) ;(1 \%)$ & Guo et al. (2009) \\
\hline UI; DBI & 7 & $57 ; 60$ & $(1 \%) ;(1 \%)$ & Guo et al. (2009) \\
\hline C20:1 & 7 & 118.71 & $(1 \%)$ & Guo et al. (2009) \\
\hline $\mathrm{C} 20: 2$ & 7 & $73 ; 55$ & $(1 \%) ;(1 \%)$ & Guo et al. (2009) \\
\hline $\mathrm{C} 16: 1$ (not corrected for BF thickness) & 7 & 62 & suggestive linkage & Uemoto et al. (2009) \\
\hline $\mathrm{C} 16: 1$ ( corrected for BF thickness) & 7 & 59 & not significant & Uemoto et al. (2009) \\
\hline $\mathrm{C} 18: 1 ; \mathrm{C} 18: 2 \mathrm{n}-6$ & 7 & $66 ; 60$ & $5 \% ; 5 \%$ & Sanchez et al. (2007) \\
\hline$C 22: 4 n-6 ; C 22: 5 n-6$ & 7 & $48 ; 48$ & $1 \% ;(1 \%)$ & Sanchez et al. (2007) \\
\hline
\end{tabular}

${ }^{1}$ Trait: $\mathrm{C} 14: 0=$ myristic acid; C16:0 = palmitic acid; C16:1 = palmitoleic acid; C16:1(n-7) = palmitelaidic acid; C16:1(n-9) = palmitoleic acid; $\mathrm{C} 17: 1=$ cis-10-heptadecenoic Acid; C18:0 = stearic acid; C18:1= oleic acid; C18:1(n-7)= vaccenic acid; C18: $1 \mathrm{n}-9=$ oleic acid; C18:2n-7 = vaccenic acid; C18:2 = linoleic acid; C18:2n-6 = linoleic acid; C18:3 = linolenic acid; C18:3(n-3) = linolenic acid; C20:1 = gadoleic acid; C20:2 = eicosadienoic acid; C20:2(n-6) = eicosadienoic acid; C20:3 = eicosatrienoic acid; C20:3n-3 = eicosatrienoic acid; C20:4 = arachidonic acid; C22:6n-3 = docosahexaenoic acid; C22:4n-6 = adrenic acid; C22:5n-6= docosapentaenoic acid; SFA = saturated fatty acids; PUFA = poly-unsaturated fatty acids; MUFA = mono-unsaturated fatty acid; $\mathrm{P} / \mathrm{S}=$ poly-unsaturated:saturated fatty acid ratio; $\mathrm{DBI}=$ double bond index

${ }^{2} \mathrm{Pc}$-value $=$ chromosome-wide $p$-value

${ }^{3}(\mathrm{Pg})$-value $=$ genome-wide $p$-value (the value in side of ( ) means the level significant in genome-wide) 
Table 2. Continued

\begin{tabular}{|c|c|c|c|c|}
\hline Trait $^{1}$ & $\begin{array}{l}\text { Pig } \\
\text { chromosome }\end{array}$ & Position (cM) & $\mathrm{Pc}^{2}(\mathrm{Pg})^{3}$ value & Reference \\
\hline C16:0; C16:1 (n-9) & 8 & $86 ; 86$ & $(p=0.05 ; p<0.01)$ & Clop et al. (2003) \\
\hline $\mathrm{C} 18: 2 ; \mathrm{C} 20: 2 ; \mathrm{C} 18: 0$ & 8 & $38 ; 40 ; 75$ & $(1 \%) ;(1 \%) ;(5 \%)$ & Guo et al. (2009) \\
\hline DBI; P/S; UI; SFA & 8 & $38 ; 39 ; 54 ; 71$ & $(1 \%) ;(1 \%) ;(1 \%)$ & Guo et al. (2009) \\
\hline $\mathrm{C} 16: 0$ & 8 & 66 & $5 \%$ & Sanchez et al. (2007) \\
\hline C16:1; SFA & 9 & $64.6 ; 78.6$ & Significant & Nii et al. (2006) \\
\hline $\mathrm{C} 18: 0$ & 9 & $67.6 \& 67.6$ & Significant & Nii et al. (2006) \\
\hline C14:0; C18:0; C20:3 & 9 & $27 ; 14 ; 88$ & $1 \% ; 1 \% ;(1 \%)$ & Sanchez et al. (2007) \\
\hline C14:0 & 10 & 82 & $(p=0.05)$ & Clop et al. (2003) \\
\hline $\mathrm{C} 14: 0$ & 10 & 66 & $(1 \%)$ & Guo et al. (2009) \\
\hline $\mathrm{C} 16: 1 ; \mathrm{C} 18: 1 ; \mathrm{C} 18: 2 \mathrm{n}-6$ & 10 & $106 ; 103 ; 108$ & $5 \% ; 5 \% ; 5 \%$ & Sanchez et al. (2007) \\
\hline C20:5; C22:5n-6; MUFA & 10 & $27 ; 42 ; 41$ & $(5 \%) ; 1 \% ;(5 \%)$ & Sanchez et al. (2007) \\
\hline $\mathrm{C} 17: 1 ; \mathrm{C} 22: 6 \mathrm{n}-3$ & 11 & $92 ; 51$ & $5 \% ; 1 \%$ & Sanchez et al. (2007) \\
\hline PUFA; P:S & 11 & $89 ; 63$ & $5 \% ; 5 \%$ & Sanchez et al. (2007) \\
\hline C14:0 (not corrected for BF thickness) & 12 & 1 & Significant & Uemoto et al. (2009) \\
\hline $\mathrm{C} 16: 1$ (not corrected for BF thickness) & 12 & 62 & Suggestive linkage & Uemoto et al. (2009) \\
\hline $\mathrm{C} 14: 0$ (corrected for BF thickness) & 12 & $1 ; 2$ & Suggestive linkage; significant I & Uemoto et al. (2009) \\
\hline C16:1 (corrected for BF thickness) & 12 & 59 & Non significant & Uemoto et al. (2009) \\
\hline C14:0; C16:0; C16:1(n-7); C18:0 & 12 & $11 ; 20 ; 68 ; 75$ & $1 \% ; 1 \% ; 1 \% ; 1 \%$ & Munoz et al. (2007) \\
\hline C18:1(n-7); C20:1(n-); C20:2(n-6) & 12 & $76 ; 34 ; 1$ & $1 \% ; 1 \% ; 1 \%$ & Munoz et al. (2007) \\
\hline $\mathrm{C} 18: 3(\mathrm{n}-3)$ & 12 & 31 & $(p=0.04)$ & Clop et al. (2003) \\
\hline $\mathrm{C} 16: 1$ & 12 & 40 & $5 \%$ & Sanchez et al. (2007) \\
\hline C16:1 & 13 & 89 & $(1 \%)$ & Guo et al. (2009) \\
\hline C18:1; C22:5n-6; MUFA & 13 & $45 ; 102 ; 45$ & $5 \% ; 5 \% ; 5 \%$ & Sanchez et al. (2007) \\
\hline C16:0 (perirenal fat) & 14 & 17.2 & Significant & Nii et al. (2006) \\
\hline $\mathrm{C} 16: 0 ; \mathrm{C} 16: 1 ; \mathrm{C} 18: 0$ & 14 & $22 ; 67 ; 67$ & $5 \% ;(1 \%) ;(0.1 \%)$ & Sanchez et al. (2007) \\
\hline $\mathrm{C} 18: 2 n-6 ; C 20: 3 n-3 ; C 22: 5 n-6$ & 14 & $22 ; 21 ; 32$ & $5 \% ; 1 \% ; 5 \%$ & Sanchez et al. (2007) \\
\hline SFA; MUFA; PUFA; P:S & 14 & $45 ; 67 ; 23 ; 23$ & $(1 \%) ; 5 \% ; 5 \% ; 1 \%$ & Sanchez et al. (2007) \\
\hline C16:0; C18:1; SFA & 15 & $35.9 ; 57 ; 45.3$ & Significant & Nii et al. (2006) \\
\hline $\mathrm{C} 14: 0$ & 15 & 44 & $(5 \%)$ & Sanchez et al. (2007) \\
\hline C16:0 (perirenal fat) & 16 & 0.0 & Significant & Nii et al. (2006) \\
\hline $\mathrm{C} 16: 0$ & 16 & 33 & $5 \%$ & Sanchez et al. (2007) \\
\hline $\mathrm{C} 18: 2$ & 17 & 62.3 & Significant & Nii et al. (2006) \\
\hline $\mathrm{C} 14: 0$ & 18 & 42.8 & Significant & Lee et al. (2003) \\
\hline C20:3; PUFA; C20:3; P/S & $\mathrm{X}$ & $50 ; 50 ; 51 ; 51$ & $(5 \%) ;(5 \%) ;(5 \%) ;(5 \%)$ & Guo et al. (2009) \\
\hline DBI; UI; C16:0; SFA & $\mathrm{X}$ & $52 ; 52 ; 53 ; 55$ & $(1 \%) ;(1 \%) ;(1 \%) ;(1 \%)$ & Guo et al. (2009) \\
\hline
\end{tabular}

on $\mathrm{SSC} 4,6,8,10$ and 12 both displayed $1 \%$ and $5 \%$ genome-wide significant effects for FA composition (Table 2). The QTL for C18:2 have been identified in pig chromosome 4. However, a QTL for backfat thickness was identified in the same region from the same pig breed (Varona et al., 2002). The discrepancy might be due to the effect of pleiotropic QTL effects between FA and backfat thickness. Also, significant QTLs were detected for the double bond index (DBI), equals the sum of the products of the mole fraction and the number of double bonds for each fatty acid, and unsaturated index (UI), the sum of the percentage unsaturated fatty acids multiplied by their number of double bonds, in SSC6. However, Ovilo et al. (2000) also reported that this location also has been associated with intramuscular fat and loin eye area. Also, de Koning et al. (1999) described the influence of this region on intramuscular fat content.

Three studies reported QTLs on SSC12 associated with eight FA composition traits, as shown in Table 2 (Clop et al., 2003; Munoz et al., 2007; Uemoto et al., 2009). Munoz et al. (2007) suggested that the QTLs closely located at the QTL region affecting C18:0 and C18:1 is in the vicinity of the ACACA gene, which was mapped at SSC12p13-p12 (Calvo et al., 2000). Moreover, Wakil et 
Table 3. List of candidate genes affecting fatty acid composition in cattle and pig

\begin{tabular}{|c|c|c|c|c|c|c|}
\hline Gene name & Species & $\begin{array}{l}\text { GenBank } \\
\text { Acc.No. }\end{array}$ & SNP name & Favorable trait ${ }^{1}$ & $\begin{array}{l}\text { Favorable geno- } \\
\text { type or haplotype }\end{array}$ & Reference \\
\hline \multirow[t]{7}{*}{ ACACA } & \multirow[t]{4}{*}{ Cattle } & \multirow[t]{2}{*}{ AJ276223 } & g. $2203 \mathrm{G}>\mathrm{T}$ & \multicolumn{2}{|c|}{$\begin{array}{l}\text { Triacylglycerol (TAG), total lipid, GG } \\
\text { total SFA and total MUFA }\end{array}$} & Zhang et al. (2009) \\
\hline & & & g. $2350 \mathrm{~T}>\mathrm{C}$ & C14:0;C14:1; C16:1; C17:1 & $\mathrm{TC}$ & Zhang et al. (2009) \\
\hline & & \multirow[t]{2}{*}{ EU168399 } & \multicolumn{2}{|c|}{ linked SNP (c.4899G >A SFA (C14:0; C16:0; C18:0), } & Haplotype & Gallardo et al. (2009) \\
\hline & & & $\begin{array}{l}\& \mathrm{c} .5196 \mathrm{~T}>\mathrm{C}) \\
\text { c. } 5634 \mathrm{~T}>\mathrm{C}\end{array}$ & PUFA (C18:2) \& MUFA & $\mathrm{A}_{4899} \mathrm{C}_{5196}$ & \\
\hline & \multirow[t]{3}{*}{ Pig } & \multirow[t]{3}{*}{ EF618729 } & & C16:1(n-9); & $\mathrm{C}$ allele & Munoz et al. (2007) \\
\hline & & & c. $6681 \mathrm{G}>\mathrm{T}$ & C18:1(n-7) & & \\
\hline & & & & C18:0 & G allele & \\
\hline \multirow[t]{11}{*}{ FASN } & \multirow[t]{11}{*}{ Cattle } & \multirow[t]{2}{*}{ AF285607 } & \multirow[t]{2}{*}{ g. $17924 \mathrm{~A}>\mathrm{G}$} & C18:1; total MUFA & GG & Zhang et al. (2008) \\
\hline & & & & C20:3 \& PUFA & AA & \\
\hline & & AF285607 & g. $17924 \mathrm{~A}>\mathrm{G}$ & C18:1; C16:0 & GG & Bhuiyan et al. (2009) \\
\hline & & \multirow[t]{2}{*}{ AF285607 } & g. $16024 A>G \&$ & C18:0; C18:1; & TW haplotype & Abe et al. (2009) \\
\hline & & & g. $16039 \mathrm{~T}>\mathrm{C}$ & Ratio MUFA: SFA & & \\
\hline & & \multirow[t]{4}{*}{ AF285607 } & \multirow{4}{*}{\multicolumn{2}{|c|}{$\begin{array}{l}32 \text { SNPs in chromosome C18:1 } \\
19 \text { (identified using Illu- } \\
\text { mina BovineSNP50 } \\
\text { BeadChip) } \\
\text { g. } 16024 \mathrm{~A}>\mathrm{G}\end{array}$}} & No information & Uemoto et al. (2010) \\
\hline & & & & & & \\
\hline & & & & & & \\
\hline & & & & & & \\
\hline & & \multirow[t]{2}{*}{ AF285607 } & \multirow{2}{*}{\multicolumn{2}{|c|}{$\mathrm{C} 18: 1$}} & Haplotype & Matsuhashi et al. (2010) \\
\hline & & & & & $\mathrm{AR}>\mathrm{TW}$ & \\
\hline LXR-alpha & Cattle & NC_007313 & 397bpG $>A(V 1331)$ & $\mathrm{C} 18: 2$ & Heterozygote & Hoashi et al. 2008 \\
\hline \multirow[t]{4}{*}{$\mathrm{SCD}$} & \multirow[t]{4}{*}{ Cattle } & NC_007327 & $878 \mathrm{bpT}>\mathrm{C}$ & MUFA \& low in melting point & Type A A & Taniguchi et al. (2004) \\
\hline & & NC_007327 & \multicolumn{2}{|c|}{$\begin{array}{l}\text { Genotype effect (no SNP C14:1; C18:1; MUFA } \\
\text { information) }\end{array}$} & Type AA & Ohsaki et al. (2009) \\
\hline & & NC_007327 & $\mathrm{A} 293 \mathrm{~V}$ & $\begin{array}{l}\text { C14:0; C14:1; C18:0; C18:1 \& } \\
\text { MUFA }\end{array}$ & AV & Matsuhashi et al. (2010) \\
\hline & & NC_007327 & \multicolumn{2}{|c|}{$\begin{array}{l}32 \text { SNPs in chromosome No effect in C18:1 } \\
19 \text { (identified using Illu- } \\
\text { mina SNP Chip) }\end{array}$} & No information & Uemoto et al. (2010) \\
\hline FABP4 & Cattle & NC_007312 & 328 bpG/A (174V) & $\mathrm{C} 16: 1$ & I/I homozygote & Hoashi et al. (2008) \\
\hline FABP3 & Pig & X98558 & $\begin{array}{l}\text { Genotype effect using } \\
\text { restriction enzyme }\end{array}$ & $\begin{array}{l}\text { SFA, MUFA \& ratio of PUFA to } \\
\text { SFA }\end{array}$ & hh genotype & Lee et al. (2010) \\
\hline МTTP & Pig & NM_214185 & c. $2573 \mathrm{~T}>\mathrm{C}$ & $\begin{array}{l}\text { C16:0; C16:1 (n-9); } \\
\text { C18:1(n-2) }\end{array}$ & $\mathrm{C}$ allele & Estelle et al. (2009) \\
\hline ACSL4 & Pig & DQ144454 & c. $2645 \mathrm{G}>\mathrm{A}$ & $\mathrm{C} 18: 2$ & No information & Mercade et al. (2006) \\
\hline \multirow[t]{3}{*}{ SREBP-1 } & \multirow[t]{3}{*}{ Cattle } & NC_007317 & \multirow{3}{*}{$\begin{array}{l}\text { 84-bp indel of SREBP-1 } \\
\text { 84-bp indel of SREBP-1 }\end{array}$} & 1 MUFA \& low melting point & SS type & Hoashi et al. (2007) \\
\hline & & NC_007317 & & $1 \mathrm{C} 18: 0$ & LL type & Bhuiyan et al. (2009) \\
\hline & & & & C18:2; PUFA & SS type & \\
\hline
\end{tabular}

${ }^{1}$ Trait: C14:0 = myristic acid; C16:0 = palmitic acid; C16:1 = palmitoleic acid; C16:1(n-9) = palmitoleic acid; C17:1= cis-10-heptadecenoic acid; C18:0 = stearic acid; C18:1 = oleic acid; C18:2= linoleic acid; SFA = saturated fatty acids; PUFA = poly-unsaturated fatty acids; MUFA=monounsaturated fatty acid

al. (1989) suggested that FASN gene is involved in the synthesis of long-chain FAs. The gene was subsequently mapped to HSA17q25 (Jayakumar et al., 1994).

In SSC13, Guo et al. (2009) reported significant QTLs associated with $\mathrm{C} 16: 1$ in both longissimus dorsi and abdominal fat. A previous study indicated the same chromosome locations harboring QTLs for C18:1, C22:5 and MUFA (Sanchez et al., 2007). From the total of 153 QTLs for FA composition in a whole genome reported by
Guo et al. (2009), no significant QTL was detected on SSC14 for the FA composition traits. On the other hand, Nii et al. (2006) reported QTLs in relation to C16:0 in perirenal fat on SSC14. In addition, in SSC14 at 59.3$60.0 \mathrm{cM}$, the SCD gene was assigned and shown to be highly responsible for conversion of SFAs in MUFA in mammalian adipocytes (Ren et al., 2003).

For SSC 15, a QTL has been associated with C16:0, C18:1 and SFA (Nii et al., 2006). The possible candidate 
gene for this region is FA coenzyme A ligase, long chain 2 (FACL2) (Vidal and Amills, 2004). The formation of fatty acyl-CoAs plays an essential role in many cellular biochemical processes such as lipid metabolism, enzyme activation and protein transport. They are used as substrate of phospholipids (Weimar et al., 2002).

\section{Candidate genes affecting FA composition}

Candidate genes are the possible causative genes that strongly affect the variations in the target traits. If the candidate genes are located in the QTL region, then they are termed positional candidate genes. The candidate genes in relation to meat quality traits including FA composition have been extensively investigated in the last few decades. In this section, we describe the candidate genes with known associations to FA composition in cattle and pig.

\section{Acetyl-CoA carboxylase alpha (ACACA)}

The ACACA enzyme is rate-limiting for the de novo synthesis of long-chain FAs (Mao et al., 2001). This enzyme plays an important role in the conversion of acetyl-CoA to malonyl-CoA (Abu-Elheiga et al., 1997) and acts as a precursor for palmitate (Gallardo et al., 2009). Malonyl-CoA inhibits the importation of FAs into the mitochondria for $\beta$-oxidation (Barber et al., 2005). This enzyme is present in cells as diverse as adipose cells, liver cells and lactating mammary gland cells. Three promoters, promoter I (PI), II (PII) and III (PIII) appear to be involved in the initiation of transcription of the ACACA gene in cattle (Mao et al., 2001). PI is the main ACACA promoter in liver cells and is very active in adipose tissue. However, PI is repressed in adipose tissue during lactation. PII is a housekeeping promoter that is expressed constituently (Luo and Kim, 1990) and PIII plays an important role in lipogenesis during lactation (Barber and Travers, 1998; Mao et al., 2001). Malonyl-CoA as the product of ACACA is the intermediate substrate for FASN (John et al., 1991) in which SFA is synthesized by FASN and undergoes elongation and/or denaturation in bovine adipose tissue to produce SFA and MUFA.

Eight single nucleotide polymorphisms (SNPs) have been identified in PI of the ACACA gene in cattle (Zhang et al., 2009). Two of these SNPs are associated with FA composition. Cattle having GG genotype of the g.2203G $>\mathrm{T}$ SNP are significantly associated with greater triacylglyserol (TAG), total lipid, total SFA and total MUFA, compared with the animals having GT genotype (Zhang et al., 2009). This result indicates that ACACA expression could catalyze the conversion of acetyl-CoA to malonyl$\mathrm{CoA}$ in the cytoplasm, serving as precursors for fat as food storage (Mao et al., 2001). Moreover, concerning the g.2350T $>$ C SNP, TC heterozygous animals were reported to possess more myristoleic acid (C14:1), palmitoleic acid (16:1) and cis-10-heptadecenoic acid (C17:1) in the longissimus dorsi than CC homozygous animals (Zhang et al., 2009).

In pigs, the ACACA gene was mapped on $\mathrm{SSC} 12$ in the QTL region at position $75.6 \mathrm{cM}$ in the Duroc commercial line (Gallardo et al., 2009; Munoz et al., 2007). Of the 21 SNPs, 10 were segregated for lipid metabolism. Two linked SNPs (c.4899G $>$ A and c.5196T $>$ C) were considered to associate with percentage of carcass lean, intramuscular fat (IMF), MUFA, SFA (myristic, palmitic and stearic) and PUFA (linoleic) in the longissimus thorachis et lumborum muscle. In addition, the same study indicated that fatter pigs had higher SFA and MUFA, but a lower percentage of PUFA. For cattle, this situation reflects dietary intake, since cattle can not synthesize PUFA precursors such as linoleic acid and linolenic acid (Zhang et al., 2009). Therefore, the percentage of PUFA in cattle remains lower than SFA and MUFA. Another study reported that the ACACA gene was a candidate gene for fatty acid composition. The ACACA c.5634C allele had a positive effect on $\mathrm{C} 16: 1 \mathrm{n}-9$ and $\mathrm{C} 18: 1 \mathrm{n}-7$, whereas c.6681G allele had a positive effect on C18:0 (Munoz et al., 2007).

\section{Fatty acid synthase (FASN)}

The FASN gene encodes a multifunctional enzyme complex that catalyses the synthesis of long chain SFA (Zhang et al., 2008). In the FASN complex, the thioesterase (TE) domain is responsible for termination of FA synthesis. Moreover, this domain has an important role in the determination of the chain length for the FASN protein. Therefore, TE domain variations are implicated as influential for differences in FA composition. TE domains are important regions in the FASN gene because they are potential substrates for elongation and denaturation that are responsible for length determination of the FASN gene. The polymorphisms detected in this TE domain may influence the structure of substrate-binding site and affect the specific activity in TE towards C14-acyl ACP (Zhang et al., 2008)

The TE domain is located near the $\mathrm{C}$ terminus of the FASN multienzyme complex (Joshi and Smith, 1993) and at the 3'-end of the FASN encoding between exons 39-42 (Zhang et al., 2008). This gene has seven active sites that help to catalyze all the reaction steps in the conversion of 
acetyl-CoA and malonyl-CoA to palmitate (Roy et al., 2005). The QTL for the FASN gene has been detected in chromosome 19 (Morris et al., 2007; Ordovas et al., 2008; Roy et al., 2006). The FASN gene is widely used to identify associations with meat quality traits including FA composition. Mutations in bovine FASN and their associations with FA composition in cattle have been documented (Abe et al., 2009, Bhuiyan et al., 2009, Matsuhashi et al., 2010, Uemoto et al., 2010, Zhang et al., 2008).

Three SNPs located in the FASN TE domain were identified in Angus bulls (Zhang et al., 2008). Two of these SNPs were revealed to be significantly associated with FA composition. The g.17924GG genotypes had significantly greater health index, C18:1 and total MUFA compared to the AA genotypes, whereas the g.17924AA genotypes were more favorable in C20:3 and PUFA. These studies differ from a study with Japanese Black cattle that detected a lower concentration of C14:0, C16:0, C14:1 and C16:1 and higher concentration of C18:0, C18:1, MUFA and SFA (Abe et al., 2009). In addition, Moris et al. (2007) identified a QTL on bovine chromosome 19 and detected that the FASN gene in the QTL region, which was associated with $\mathrm{C} 14: 0$ in subcutaneous adipose tissue and milk fat. Another study reported five SNPs in the FASN TE domain that were identified in Korean Hanwoo cattle. Of these SNPs, significant associations were identified with C16:0 and oleic C18:1 (Bhuiyan et al., 2009). In case of Japanese Black and Limousin cattle, the TW FASN gene haplotype had significant effects with increasing C18:0 and C18:1 and decreasing C14:0, C14:1, C16:0 and C16:1 (Abe et al., 2009). Using haplotype analysis, Matsuhashi et al. (2010) reported that the $\mathrm{AR}>\mathrm{TW}$ haplotype of the FASN gene was decreasing the proportion of C14:0, C14:1, C16:0 and C161, but increasing C18:1. Very recently, FASN was associated with C18:1 within Japanese Black cattle using Illumina Bovine SNP50 BeadChip (Uemoto et al., 2010).

The porcine FASN gene has been mapped on chromosome 12 (Jayakumar et al., 1994; Wakil, 1989) and the FASN map location was consistent with the comparative mapping information between human and pig (Munoz et al., 2003). Previously, Clop et al. (2003) identified a significant QTL for backfat FA composition and related metabolic traits. However, no study has reported an association of the FASN gene with FA composition in pig.

\section{Stearoyl-CoA desaturase (SCD)}

The SCD gene has been extensively studied in cattle, compared with pig and chicken. SCD is an enzyme that catalyzes the conversion of SFA into MUFA in mammalian adipocytes (Taniguchi et al., 2004) and catalyzes the delta $(\Delta) 9$ desaturation of SFA and MUFA (Ohsaki et al., 2009). SCD also contributes the synthesis of UFAs by insertion of a cis-double bond in the delta 9 position of FA substrate (Kim and Ntambi, 1999). The preferable substrates are palmitate and stearate, which are converted to palmitoleate and oleate, respectively. These substrates are the major constituent membrane phospholipids and triacylglycerol that is stored in adipose tissue. The ratio of stearic acid to oleic acid is one of the important factors influencing membrane fluidity, and this ratio plays an important role in various human diseases such as cancer, diabetes, obesity, hypertantion and neurological disease (Ntambi, 1995).

The type A SCD gene has been linked to high a MUFA percentage and low melting point in the intramuscular fat of Japanese Black cattle (Taniguchi et al., 2004). The lower melting point contributes positively to favorable beef flavor and tenderness. Similarly, Taniguchi et al. (2004) analyzed the level of SCD mRNA expression in muscle and fat tissue in different breeds, and reported that a transcriptional regulator of SREBP1 (sterol responsibleelement binding protein 1c) might affect MUFA variation.

Ohsaki et al. (2009) reported the effect of SCD genotypes in the sire of Japanese Black cattle; there were highly significant associations with C14:1, C18:0, C18:1, MUFA, SFA, MUFA/SFA, C14:1/C14:0+C14:1 and C18:1 /C18:0+C18:1. However, based on the Tukey's HSD (Honestly Significant Differences) test, the SCD gene showed significant effects or has favorable traits in C14:1, C18:1 and MUFA. A previous study in the same cattle reported that animals having AA genotype of the SCD gene have a higher MUFA and a lower melting point (Taniguchi et al. 2004). However, the authors suggested that SCD was not a major factor for FA composition in Japanese Black cattle because SCD genotypes contributed to only $4 \%$ of MUFA variation. Another study reported that the AV genotype in bovine SCD gene displays a statistically higher level of C14:0, C14:1, C18:0, C18:1 and MUFA (Matsushasi et al., 2010). However, a very recent study using Illumina BovineSNP50 did not reveal an association between the SCD gene and C18:1 (Uemoto et al., 2010).

\section{Fatty acid binding proteins (FABPs)}

FABPs belong to the member of a superfamily of lipidbinding protein (Chmurzynska, 2006). The FABP genes 
are divided into two main groups based on the cellular level: FABPs located in plasma membrane and those that are intracellular or cytoplasmic (Glatz and van der Vusse 1996). Based on the tissue-specific distribution, Chmurzynska (2006) reviewed FABPs in nine different tissues and designated them as: $\mathrm{L}$ (liver), I (intestinal), $\mathrm{H}$ (muscle and hearth), A (adipocyte), E (epidermal), Il (ileal), B (brain), $\mathrm{M}$ (myelin) and $\mathrm{T}$ (testis).

FABPs act mainly as FA transporters in the metabolic pathway (Estelle et al., 2009), where the peroxisome proliferators-activated receptor (PPAR) family members cooperatively participate as transcription factors. Therefore, the PPAR family plays an important role in regulating the transcription of many genes involved in lipid metabolisms (Desvergne and Wahli, 1999).

Many studies have been carried out for the association with FABP polymorphisms and fat-related traits in animals. In cattle, the association between FABP4 polymorphisms and fatty acid composition (C16:1) has been identified (Hoashi et al., 2008). This FABP4 gene also affects the marbling and subcutaneous fat in Wagyu and Limousin F2 crosses (Michal et al., 2006) and IMF in Australian cattle (Barendse et al., 2009). In Korean cattle (Hanwoo), the FABP4 gene was associated with backfat thickness (Cho et al., 2008), marbling and carcass weight (Lee et al., 2010). However, no association was evident between FABP4 and IMF in crossbred Bos taurus cattle (Pannier et al., 2010).

In pig, some FABP family members are involved in fatrelated traits. Heart-FABP (H-FABP; FABP3) is most widely investigated gene in relation to fat. Significant associations between the H-FABP gene and IMF contents have been reported in pig (Arnyasi et al., 2006; Gerbens et al., 2001; Li et al., 2006; Urban et al., 2002). H-FABP was also significantly associated with backfat thickness in purebred Yorkshire pigs (Cho et al., 2010) and Polish Large White and Polish Landrace (Chmurzynska et al., 2007). In addition, the positional candidate gene, FABP2, has been investigated for the QTL on porcine chromosome 8. The association between FABP2 and FA composition was not be significant (Estelle et al., 2009). However, pigs having hh genotypes had higher UFA content, and a higher ratio of PUFA to SFA in Berkshire breed (Lee et al., 2010).

\section{Other candidate genes}

The microsomal triglyceride transfer protein (MTTP) gene provides instructions for the manufacture of microsomal triglyceride transfer protein. This gene plays an essential role in lipid transfer during the assembly of lipoproteins in the liver and intestine (Hussain et al., 2003). A MTTP gene SNP was highly associated with palmitoleic acid and oleic acid in a F2 cross pig population (Estelle et al., 2009). The most likely explanation is that the FA composition of monogastric meat and fat depends mainly on dietary fat (Mourot and Hermier 2001). However, weight and slaughter age also contributes to the differences in FA profile.

Long-chain-CoA synthase 4 (ACSL4) is a member of the ACSL family that is involved in the two main metabolic pathways: the pathway for anabolic conversion of FAs to cellular lipids and the pathway for catabolism of FAs through $\beta$-oxidation (Van Horn et al., 2005). Mercade et al. (2006) reported that the ACSL4 polymorphisms were associated with percentage of oleic FA in pigs.

Sterol regulatory binding proteins (SREBPs) are membrane bound transcription factors that function mainly in energy homeostasis by promoting glycolysis, lipogenesis and adipogenesis (Hoashi et al., 2007). The SREBP1 gene regulates the enzyme responsible for synthesis of cholesterol, FA and the low density lipoprotein receptor (Horton et al., 1998). This gene is closely related with the SCD gene. The expression level of the SREBP1 gene may affect the expression level of SCD gene, leading to differences in FA composition. Polymorphisms in an 84 bp insertion/deletion (indel) in intron 5 of the bovine SREBP-a gene have been associated with higher MUFA and lower melting point in the SS genotype of Japanase Black cattle (Hoashi et al., 2007). A similar study in Korean cattle (Hanwoo) reported higher C18:0 and C18:2 with the LL and SS genotype, respectively (Bhuiyan et al., 2009).

\section{Conclusion}

QTLs and candidate genes, which were associated with FA composition, have been amply identified in cattle and pig. The present review can give a useful guideline for the current researches for FA composition in cattle and pig. Appropriate markers, that will be developed soon, can be applied to select animals that produce healthy and good quality beef and pork. Therefore, more molecular markers are developed, animal and meat industry will have benefits not only for decreasing of the selection intervals, but also producing meat products that consumers need. 


\section{Acknowledgement}

This work was supported by a grant from the NextGeneration BioGreen 21 Program (Project Number PJ008133). Rural Development Administration, Republic of Korea.

\section{References}

1. Abe, T., Saburi, J., Hasebe, H., Hasebe, T., Misumi, S., Nade, T., Nakajima, H., Shoji, N., Kobayashi, M., and Kobayashi, E. (2009) Novel mutations of the FASN gene and their effect on fatty acid composition in Japanese Black beef. Biochem. Genet. 47, 397-411.

2. Abu-Elheiga, L., Almarza-Ortega, D. B., Baldini, A., and Wakil, S. J. (1997) Human acetyl-CoA carboxylase 2 Molecular cloning, characterization, chromosomal mapping, and evidence for two isoforms. J. Biol. Chem. 272, 10669-10677.

3. Alexander, L. J., Macneil, S. J., Geary, T. W., Snelling, W. M., Rule, D. C., and Scanga, J. A. (2007) Quantitative trait loci with additive effects on palatability and fatty acid composition of meat in a Wagyu-Limousin F2 population. Anim. Genet. 38, 506-513.

4. Alfaia, C. P. M., Alves, S. P., Martins, S. I. V., Costa, A. S. H., Fontes, C. M. G. A., Lemos, J. P. C., Bessa, R. J. B., and Prates, J. A. M. (2009) Effect of the feeding system on intramuscular fatty acids and conjugated linoleic acid isomers of beef cattle, with emphasis on their nutritional value and discriminatory ability. Food Chem. 114, 939-946.

5. Animal Quantitative Trait Locus (QTL) database (AnimalQTLdb). Available from: http://www.animalgenome.org/ cgi-bin/QTLdb/index. Accessed Dec. 20, 2010.

6. Arnyasi, M., Grindflek, E., Javor, A., and Lien, S. (2006) Investigation of two candidate genes for meat quality traits in a quantitative trait locus region on SSC6: the porcine short heterodimer partner and heart fatty acid binding protein genes. J. Anim. Breed. Genet. 123, 198-203.

7. Barber, M. C. and Travers, M. T. (1998) Elucidation of a promoter activity that directs the expression of acetyl-CoA carboxylase alpha with an alternative N-terminus in a tissuerestricted fashion. Biochem. J. 333, 17-25.

8. Barber, M. C., Price, N. T., and Travers, M. T. (2005) Structure and regulation of acetyl-CoA carboxylase genes of metazoa. Biochim. Biophys. Acta 1733, 1-28.

9. Barendse, W., Bunch, R. J., Thomas, M. B., and Harrison, B. E. (2009) A splice site single nucleotide polymorphism of the fatty acid binding protein 4 gene appears to be associated with intramuscular fat deposition in longissimus muscle in Australian cattle. Anim. Genet. 40, 770-773.

10. Beuzen, N. D., Stear, M. J., and Chang, K. C. (2000) Molecular markers and their use in animal breeding. The Vet. J. 160, 42-52.

11. Bhuiyan, M. S. A., Yu, S. L., Jeon, J. T., Yoon, D., Cho, Y. M., Park, E. W., Kim, E. W., Kim, K. S., and Lee, J. H. (2009) DNA polymorphisms in SREBF1 and FASN genes affect fatty acid composition in Korean cattle (Hanwoo). Asian-Aust. J. Anim. Sci. 22, 765-773.

12. Bou, R., Codony, R., Tres, A., Decker, E. A., and Guardiola, F. (2009) Dietary strategies to improve nutritional value, oxidative stability, and sensory properties of poultry products. Crit. Rev. Food Sci. Nutr. 49, 800-822.

13. Calvo, J. H., Lopez-Corrales, N. L., Anderson, S. I., Skinner, T. M., Marcos, S., Osta, R., Archibald, A. L., and Zaragoza, P. (2000) Assignment of acetyl-coenzyme A carboxylase alpha (ACACA) to pig chromosome $12(12 \mathrm{p} 13 \rightarrow \mathrm{p} 12)$ by fluorescence in situ hybridization and confirmation by genetic mapping. Cytogenet. Cell Genet. 90, 238-239.

14. Casas, E., Shackelford, S. D., Keele, J. W., Koohmaraie, M., Smith, T. P., and Stone, R. T. (2003) Detection of quantitative trait loci for growth and carcass composition in cattle. $J$. Anim. Sci. 81, 2976-2983.

15. Cho, S., Park, T. S., Yoon, D. H., Cheong, H. S., Namgoong, S., Park, B. L., Lee, H. W., Han, C. S., Kim, E. M., Cheong, I. C., Kim, H., and Shin, H. D. (2008) Identification of genetic polymorphisms in FABP3 and FABP4 and putative association with back fat thickness in Korean native cattle. BMB Rep. 41, 29-34.

16. Cho, K. H., Kim, M. J., Jeon, G. J., and Chung, H. Y. (2010) Association of genetic variants for FABP3 gene with back fat thickness and intramuscular fat content in pig. Mol. Biol. Rep. 38, 2161-2166.

17. Clop, A., Ovilo, C., Perez-Enciso, M., Cercos, A., Tomas, A., Fernandez, A., Coll, A. , Folch, J. M., Barragan, C., Diaz, I., Oliver, M. A., Varona, L., Silio, L., Sanchez, A., and Noguera, J. L. (2003) Detection of QTL affecting fatty acid composition in the pig. Mamm. Genome 14, 650-656.

18. Chmurzynska, A. (2006) The multigene family of fatty acidbinding proteins (FABPs): function, structure and polymorphism. J. Appl. Genet. 47, 39-48.

19. Chmurzynska, A., Szydlowski, M., Stachowiak, M., Stankiewicz, M., and Switonski, M. (2007) Association of a new SNP in promoter region of the porcine FABP3 gene with fatness traits in a polish synthetic line. Anim. Biotechnol. 18, 37-44.

20. Decker, E. A. and Park, Y. (2010) Healthier meat products as functional foods. Meat Sci. 86, 49-55.

21. de Koning, D. J., Janss, L. L., Rattink, A. P., van Oers, P. A., de Vries, B. J., Groenen, M. A., van der Poel, J. J., de Groot, P. N., Brascamp, E. W., and van Arendonk, J. A. (1999) Detection of quantitative trait loci for backfat thickness and intramuscular fat content in pigs (Sus scrofa). Genetics 152, 1679-1690.

22. Desvergne, B. and Wahli, W. (1999) Peroxisome proliferator-activated receptors: nuclear control of metabolism. Endocr. Rev. 20, 649-688.

23. Diana, P., Nichols, P. J., and Thompson, J. M. (1998) The effect of sire breed on the melting point and fatty acid composition of subcutaneous fat in steers. J. Anim. Sci. 76, 8795.

24. Enser, M. and Wood, J. D. (1993) Effect of time of year on fatty acid composition and melting point of UK lamb. Pro- 
ceed. 39th International Cong. Meat Sci. Technol., Calgary, Canada, pp 74.

25. Estelle, J., Mercade, A., Perez-Enciso, M., Pena, R. N., Silio, L., Sanchez, A., and Folch, J. M. (2009a) Evaluation of FABP2 as candidate gene for a fatty acid composition QTL in porcine chromosome 8. J. Anim. Breed. Genet. 126, 52-58.

26. Estelle, J., Fernandez, A. I., Perez-Enciso, M., Fernandez, A., Rodriguez, C., Sanchez, A., Noguera, J. L., and Folch, J. M. (2009b) A non-synonymous mutation in a conserved site of the MTTP gene is strongly associated with protein activity and fatty acid profile in pigs. Anim Genet. 40, 813-820.

27. Food and Agricultural Organization (2003) Diet, nutrition and the prevention of chronic disease. Report of joint WHO/ FAO expert consultant, Rome, Italy.

28. Gallardo, D., Quintanilla, R., Varona, L., Diaz, I., Ramirez, O., Pena, R. N., and Amills, M. (2009) Polymorphism of the pig acetyl-coenzyme A carboxylase alpha gene is associated with fatty acid composition in a Duroc commercial line. Anim. Genet. 40, 410-417.

29. Gerbens, F., Verburg, F. J., Van Moerkerk, H. T. B., Engel, W., Buist, J. H., Veerkamp, and te Pas, M. F. (2001) Associations of heart and adipocyte fatty acid-binding protein gene expression with intramuscular fat content in pigs. J. Anim. Sci. 79, 347-354.

30. Glatz, J. F. C. and van der Vusse, G. J. (1996) Cellular fatty acid binding proteins: their function and physiological significance. Prog. Lipid Res. 35, 243-282.

31. Guo, T., Ren, J., Yang, K., Ma, J., Zhang, Z., and Huang, L. (2009) Quantitative trait loci for fatty acid composition in longissimus dorsi and abdominal fat: results from a White Duroc x Erhualian intercross F2 population. Anim. Genet. 40, 185-191.

32. Gutierrez-Gil, B., Wiener, P., Nute, G. R., Burton, D., Gill, J. L., Wood, J. D., and Williams, J. L. (2008) Detection of quantitative trait loci for meat quality traits in cattle. Anim. Genet. 39, 51-61.

33. Gutierrez-Gil, B., Wiener, P., Richardson, R. I., Wood, J. D., and Williams, J. L. (2010) Identification of QTL with effects on fatty acid composition of meat in a Charolais $\mathrm{x}$ Holstein cross population. Meat Sci. 85, 721-729.

34. Hoashi, S., Ashida, N., Ohsaki, H., Utsugi, T., Sasazaki, S., Taniguchi, M., Oyama, K., Mukai, F., and Mannen, H. (2007) Genotype of bovine sterol regulatory element binding protein-1 (SREBP-1) is associated with fatty acid composition in Japanese Black cattle. Mamm. Genome 18, 880-886.

35. Hoashi, S., Hinenoya, T., Tanaka, A., Ohsaki, H., Sasazaki, S., Taniguchi, M., Oyama, K., Mukai, F., and Mannen, H. (2008) Association between fatty acid compositions and genotypes of FABP4 and LXR-alpha in Japanese black cattle. BMC Genet. 9, 84-90.

36. Horton, J. D., Bashmakov, Y., Shimomura, I., and Shimano, H. (1998) Regulation of sterol regulatory element binding proteins in livers of fasted and refed mice. P. Natl. Acad. Sci. USA 95, 5987-5992.

37. Hussain M. M., Shi, J., and Dreizen, P. (2003) Microsomal triglyceride transfer protein and its role in apoB-lipoprotein assembly. J. Lipid Res. 44, 22-32.

38. Jayakumar, A., Chirala, S. S., Chinault, A. C., Baldini, A., Abu-Elheiga, L., and Wakil, S. J. (1994) Isolation and chromosomal mapping of genomic clones encoding the human Fatty Acid Synthase Gene. Genomics 23, 420-424.

39. John, L. C., Lunt, D. K., and Smith, S. B. (1991) Fatty acid elongation and desaturation enzyme activities of bovine liver and subcutaneous adipose tissue microsomes. J. Anim. Sci. 69, 1064-1073.

40. Joshi, A. K. and Smith, S. (1993) Construction, expression, and characterization of a mutated animal fatty acid synthase deficient in the dehydrase function. J. Biol. Chem. 268, 22508-22513.

41. Jung S., Choe, J. H., Kim, B., Yun, H., Kruk, Z. A., and Jo, C. (2010) The effect of dietary mixture of gallic acid and linoleic acid on antioxidative potential and quality of breast meat from broilers. Meat Sci. 86, 520-526.

42. Keys, A., Grande, F., and Anderson, J. T. (1974) Bias and Misrepresentationrevisite perspective in saturated fat. Am. J. Clin. Nutr. 27, 188-212.

43. Kim, Y. C. and Ntambi, J. M. (1999) Regulation of stearoylCoA desaturase genes: role in cellular metabolism and preadipocyte differentiation. Biochem. Biophys. Res. Commun. 266, 1-4.

44. Kim, Y., Kong, M., Nam, Y. J., and Lee, C. (2006) A quantitative trait locus for oleic fatty acid content on Sus scrofa chromosome 7. J. Hered. 97, 535-537.

45. Kim, J. H., Hwangbo, J., Choi, N. J., Park, H. G., Yoon, D. H., Park, W., Lee, S. H., Park, B. K., and Kim, Y. F. (2007) Effect of dietary supplementation with conjugated linoleic acid, with oleic, linoleic, or linolenic acid, on egg quality characteristics and fat accumulation in the egg yolk. Poultry Sci. 86, 1180-1186.

46. Lee, C., Chung, Y., and Kim, J. H. (2003) Quantitative trait loci mapping for fatty acid contents in the backfat on porcine chromosomes 1, 13, and 18. Mol. Cells 15, 62-67.

47. Lee, S. H., van der Werf, J. H., Park, E. W., Oh, S. J., Gibson, J. P., and Thompson, J. M. (2010) Genetic polymorphisms of the bovine fatty acid binding protein 4 gene are significantly associated with marbling and carcass weight in Hanwoo (Korean cattle). Anim. Genet. 41, 442-444.

48. Li, C. L., Pan, Y. C., Meng, H., Wang, Z. L., and Huang, X. G. (2006) Distributions of polymorphism of ADD1, MC4R, $\mathrm{H}-\mathrm{FABP}$ gene, associated with IMF and $\mathrm{BF}$ in 3 populations in pig. Yi Chuan 28, 159-164.

49. Luo, X. C. and Kim, K. H. (1990) An enhancer element in the house-keeping promoter for acetyl-CoA carboxylase gene. Nucleic Acids Res. 18, 3249-3254.

50. Malau-Aduli, A. E., Siebert, B. D., Bottema, C. D., and Pitchford, W. S. (1998) Breed comparison of the fatty acid composition of muscle phospholipids in Jersey and Limousin cattle. J. Anim. Sci. 76, 766-773.

51. Mao, J., Marcos, S., Davis, S. K., Burzlaff, J., and Seyfert, H. M. (2001) Genomic distribution of three promoters of the bovine gene encoding acetyl-CoA carboxylase alpha and evidence that the nutritionally regulated promoter I contains 
a repressive element different from that in rat. Biochem. $J$. 358, 127-135.

52. Matsuhashi, T., Maruyama, S., Uemoto, Y., Kobayashi, N., Mannen, H., Abe, T., Sakaguchi, S., and Kobayashi, E. (2010) Effects of FASN, SCD, SREBP1 and GH gene polymorphisms on fatty acid composition and carcass traits in Japanese Black cattle. J. Anim. Sci. 89, 12-22.

53. Melton S. L., Amiri M., Davis, G. W., and Backus, W. R. (1982) Flavor and chemical characteristics of ground beef from grass-, forage-, grain and grain-finished steers. J. Anim. Sci. 55, 77-87.

54. Mercade, A., Estelle, J., Perez-Enciso, M., Varona, L., Silio, L., Noguera, J. L., Sanchez, A., and Folch, J. M. (2006) Characterization of the porcine acyl-CoA synthetase longchain 4 gene and its association with growth and meat quality traits. Anim. Genet. 37, 219-224.

55. Michal, J. J., Zhang, Z. W., Gaskins, C. T., and Jiang, Z. (2006) The bovine fatty acid binding protein 4 gene is significantly associated with marbling and subcutaneous fat depth in Wagyu x Limousin F2 crosses. Anim. Genet. 37, 400-402.

56. Mizoguchi, Y., Watanabe, T., Fujinaka, K., Iwamoto, E., and Sugimoto, Y. (2006) Mapping of quantitative trait loci for carcass traits in a Japanese Black (Wagyu) cattle population. Anim. Genet. 37, 51-54.

57. Morris, C. A., Cullen, N. G., Glass, B. C., Hyndman, D. L., Manley, T. R., Hickey, S. M., McEwan, J. C., Pitchford, W. S., Bottema, C. D., and Lee, M. A. (2007) Fatty acid synthase effects on bovine adipose fat and milk fat. Mamm. Genome 18, 64-74.

58. Mourot, J. and Hermier, D. (2001) Lipids in monogastric animal meat. Reprod. Nutri. Develop. 41, 109-18.

59. Munoz, G., Ovilo, C., Noguera, J. L., Sanchez, A., Rodriguez, C., and Silio, L. (2003) Assignment of the fatty acid synthase (FASN) gene to pig chromosome 12 by physical and linkage mapping. Anim. Genet. 34, 234-235.

60. Munoz, G., Alves, E., Fernandez, A., Ovilo, C., Barragan, C., Estelle, J., Quintanilla, R., Folch, J. M., Silio, L., Rodriguez, M. C., and Fernandez, A. I. (2007) QTL detection on porcine chromosome 12 for fatty-acid composition and association analyses of the fatty acid synthase, gastric inhibitory polypeptide and acetyl-coenzyme A carboxylase alpha genes. Anim. Genet. 38, 639-646.

61. Nii, M., Hayashi, T., Tani, F., Niki, A., Mori, N., FujishimaKanaya, N., Komatsu, M., Aikawa, K., Awata, T., and Mikawa, S. (2006) Quantitative trait loci mapping for fatty acid composition traits in perirenal and back fat using a Japanese wild boar x Large White intercross. Anim. Genet. 37, 342-347.

62. Noci, F., French, P., Monahan, F. J., and Moloney, A. P. (2007) The fatty acid composition of muscle fat and subcutaneous adipose tissue of grazing heifers supplemented with plant oil-enriched concentrates. J. Anim .Sci. 85, 1062-1073.

63. Ntambi, J. M. (1995) The regulation of stearoyl-CoA desaturase (SCD). Prog. Lipid Res. 34, 139-150.

64. Ohsaki, H., Tanaka, A., Hoashi, S., Sasazaki, S., Oyama, K., Taniguchi, M., Mukai, F., and Mannen, H. (2009) Effect of
SCD and SREBP genotypes on fatty acid composition in adipose tissue of Japanese Black cattle herds. J. Anim. Sci. 80, 225-232.

65. Ordovas, L., Roy, R., Pampin, S., Zaragoza, P., Osta, R., Rodriguez-Rey, J. C., and Rodellar, C. (2008) The g.763G $>$ C SNP of the bovine FASN gene affects its promoter activity via Sp-mediated regulation: implications for the bovine lactating mammary gland. Physiol. Genomics 34, 144-148.

66. Ovilo, C., Perez-Enciso, M., Barragan, C., Clop, A., Rodriquez, C., Oliver, M. A., Toro, M. A., and Noruera, J. L. (2000) A QTL for intramuscular fat and backfat thickness is located on porcine chromosome 6. Mamm. Genome 11, 344-346.

67. Pannier, L., Mullen, A. M., Hamill, R. M., Stapleton, P. C., and Sweeney, T. (2010) Association analysis of single nucleotide polymorphisms in DGAT1, TG and FABP4 genes and intramuscular fat in crossbred Bos taurus cattle. Meat Sci. 85, 515-518.

68. Perez-Enciso, M., Clop, A., Noguera, J. L., Ovilo, C., Coll, A., Folch, J. M., Babot, D., Estany, J., Oliver, M. A., Diaz, I., and Sanchez, A. (2000) A QTL on pig chromosome 4 affects fatty acid metabolism: evidence from an Iberian by Landrace intercross. J. Anim. Sci. 78, 2525-2531.

69. Ren, J., Knorr, C., Habermann, F., Fries, R., Huang, L. S., and Brenig, B. (2003) Assignment of the porcine stearoylCoA desaturase (SCD) gene to SSC14q27 by fluorescence in situ hybridization and by hybrid panel mapping. Anim. Genet. 34, 471-473.

70. Roy, R., Gautier, M., Hayes, H., Laurent, P., Osta, R., Zaragoza, P., Eggen, A., and Rodellar, C. (2001) Assignment of the fatty acid synthase (FASN) gene to bovine chromosome $19(19 \mathrm{q} 22)$ by in situ hybridization and confirmation by somatic cell hybrid mapping. Cytogenet. Cell Genet. 93, 141-142.

71. Roy, R., Zaragoza, P., Gautier, M., Eggen, A., and Rodellar, C. (2005) Radiation hybrid and genetic linkage mapping of two genes related to fat metabolism in cattle: fatty acid synthase (FASN) and glycerol-3-phosphate acyltransferase mitochondrial (GPAM). Anim. Biotechnol. 16, 1-9.

72. Roy, R., Ordovas, L., Zaragoza, P., Romero, A., Moreno, C., Altarriba, J., and Rodellar, C. (2006) Association of polymorphisms in the bovine FASN gene with milk-fat content. Anim. Genet. 37, 215-218.

73. Sanchez, M. P., Iannuccelli, N., Basso, B., Bidanel, J. P., Billon, Y., Gandemer, G., Gilbert, H., Larzul, C., Legault, C., Riquet, J., Milan, D., and Le Roy, P. (2007) Identification of QTL with effects on intramuscular fat content and fatty acid composition in a Duroc x Large White cross. BMC Genet. 8:55-63.

74. Smith, S. B., Lunt, D. K., Chung, K. Y., Choi, C. B., Tume, R. K., and Zembayashi, M. (2006) Adiposity, fatty acid composition, and delta-9 desaturase activity during growth in beef cattle. Anim. Sci. J. 77, 478-486.

75. Taniguchi, M., Utsugi, T., Oyama, K., Mannen, H., Kobayashi, M., Tanabe, Y., Ogino, A., and Tsuji, S. (2004) Genotype of stearoyl-coA desaturase is associated with fatty acid composition in Japanese Black cattle. Mamm. Genome 15, 
142-148.

76. Taylor, J. F., Countiho, L. L., Herring, K. K., Gallagher, D. S., Brennemen, R. A., Burney, N., Sanders, J. O., Turner, J. W., Smith, S. B., Miller, R. K., Savell, J. W., and Davis, S. K. (1998) Candidate gene analysis of GHI for effect on growth and carcass characteristics of cattle. Anim. Genet. 29, 194201.

77. Tshipuliso, N. O. M., Alexander, L. J., Geary, T. W., Snelling, W. M., Rule, D. C., Koltes, J. E., Mote, B. E., and MacNeil, M. D. (2008) Mapping QTL for fatty acid composition that segregates between the Japanese Black and Limousine cattle breed. S. Afr. J. Anim. Sci. 38, 126-130.

78. Uemoto, Y., Sato, S., Ohnishi, C., Terai, S., Komatsuda, A., and Kobayashi, E. (2009) The effects of single and epistatic quantitative trait loci for fatty acid composition in a Meishan x Duroc crossbred population. J. Anim. Sci. 87, 3470-3476.

79. Uemoto, Y., Abe, T., Tameoka, N., Hasebe, H., Inoue, K., Nakajima, H., Shoji, N., Kobayashi, M., and Kobayashi, E. (2010) Whole-genome association study for fatty acid composition of oleic acid in Japanese Black cattle. Anim. Genet. 42, 141-148.

80. Urban, T., Mikolasova, R., Kuciel, J., Ernst, M., and Ingr, I. (2002) A study of associations of the H-FABP genotypes with fat and meat production of pigs. J. Appl. Genet. 43, 505509.

81. Van Horn, C. G., Caviglia, J. M., Li, L. O., Wang, S., Granger, D. A., and Coleman, R. A. (2005) Characterization of recombinant longchain rat acyl-CoA synthetase isoforms 3 and 6: identification of a novel variant of isoform 6. Biochemistry 8, 1635-1642.

82. Varona, L., Ovilo, C., Clop, A., Noguera, J. L., Perez-Enciso, M., Coll, A., Folch, J. M., Barragan, C., Toro, M. A., Babot, D., and Sanchez, A. (2002) QTL mapping for growth and carcass traits in an Iberian by Landrace pig intercross: additive, dominant and epistatic effects. Genet. Res. 80, 145-154.

83. Vidal, O. and Amills, M. (2004) Assignment of the fatty acid Coenzyme A ligase, long chain 2 (FACL2) gene to porcine chromosome 15. Anim. Genet. 35, 245.

84. Wakil, S. J. (1989) Fatty acid synthase, a proficient multifunctional enzyme. Biochemistry 28, 4523-4530.

85. Weimar, J. D., DiRusso, C. C., Delio, R., and Black, P. N. (2002) Functional role of fatty acyl-coenzyme A synthetase in the transmembrane movement and activation of exogenous long-chain fatty acids. Amino acid residues within the ATP/AMP signature motif of Escherichia coli FadD are required for enzyme activity and fatty acid transport. J. Biol. Chem. 277, 29369-29376.

86. Westerling, D. B. and Hedrick, H. B. (1979) Fatty acid composition of bovine lipids as influenced by diet, sex and anatomical location and relationship to sensory characteristics. J. Anim. Sci. 48, 1343-1348.

87. Wood, J. D., Richardson, R. I., Nute, G. R., Fisher, A. V., Campo, M. M., Kasapidou, E., Sheard, P. R., and Enser, M. (2004) Effects of fatty acids on meat quality: a review. Meat Sci. 66, 21-32.

88. Wood, J. D., Enser, M., Fisher, A. V., Nute, G. R., Sheard, P. R., Richardson, R. I., Hughes, S. I., and Whittington, F. M. (2008) Fat deposition, fatty acid composition and meat quality: A review. Meat Sci. 78, 343-358.

89. Woolett, L. A., Spady, D. K., and Dietchy, J. M. (1992) Saturated and unsaturated fatty acid independently regulate low density lipoprotein receptor activity and production rate. $J$. Lipid Res. 33, 77-88.

90. World Health Organization. (2003) WHO/FAO release independent Expert Report on diet and chronic disease. Available from: http://www.who.int/mediacentre/news/releases/2003/ pr20/en/. Accessed Dec. 29, 2010.

91. Yang, A., Larsen, T. W., Powell, V. H., and Tume, R. K. (1999) A comparison fat composition of Japanese and Longterm grain-fed Australian steers. Meat Sci. 51:1-9.

92. Zhang, S., Knight, T. J., Stalder, K. J., Goodwin, R. N., Lonergan, S. M., and Beitz, D. C. (2007) Effects of breed, sex, and halothane genotype on fatty acid composition of pork longissimus muscle. J. Anim. Sci. 85, 583-591.

93. Zhang, S., Knight, T. J., Reecy, J. M., and Beitz, D. C. (2008) DNA polymorphisms in bovine fatty acid synthase are associated with beef fatty acid composition. Anim. Genet. 39, 6270.

94. Zhang, S., Knight, T. J., Reecy, J. M., Wheeler, T. L., Shackelford, S. D., Cundiff, L.V., and Beitz, D. C. (2009) Associations of polymorphisms in the promoter I of bovine acetylCoA carboxylase-alpha gene with beef fatty acid composition. Anim. Genet. 41, 417-420.

(Received 2011.1.31/Revised 2011.5.2/Accepted 2011.5.2) 